"Law is experience developed by reason and applied continually to further experience."

Roscoe Pound

\title{
THE PREROGATIVE WRITS - INDIAN PERSPECTIVE
}

DOI:10.47743/rdc-2016-2-0003

Dr. Harsh PATHAK'

$M B A, L L B, P h D$, Advocate, Supreme Court of India

\section{Summary}

The Constitution of India broadly provides for five kinds of "prerogative" writs: habeas corpus, certiorari, mandamus, quo warranto and prohibition. This study presents their legal status, namely their application, procedure and grounds for their application.

The study concludes that, in India, the rule of law is supreme and judiciary has the right to interfere whenever there is deviation from this supremacy. The judiciary shall ensure that all administrative actions comply with legal limits and consider administrative measures to assess whether the authority has exercised powers, the authority misused or exceeded its powers, the authority committed an error of law, the authority violated principles of impartiality of the judiciary, the authority has violated the fundamental rights of individuals. The Judiciary stands to ensure that all administrative actions are confined to the limits of the law and examines administrative action to assess whether the authority has exercised its powers, whether the authority has abused or exceeded its powers, whether the authority has committed an error of law, whether the authority has violated the principles of natural justice, whether the authority has infringed the fundamental rights of persons.

Keywords: common law; prerogative writs; habeas corpus; certiorari; mandamus; quo warranto; prohibition

\section{Introduction}

In English common law, a writ is a formal written order issued by a body with administrative or judicial jurisdiction. In modern usage, this body is generally a court. Warrants, prerogative writs and subpoenas are common types of writ but innumerable forms exist.

\footnotetext{
1E-mail-dr.harshpathak@gmail.com,law.delhi@gmail.com.
} 
One of the most important subset of class of writs are the "prerogative" writs, as far as the writ jurisdiction of Courts is concerned. When Writ Jurisdiction of a court is invoked, these cases are to be heard ahead of any other cases on a court's docket except other such writs. The most common of the prerogative writs are habeas corpus, quo warranto, prohibito, mandamus, procedendo, and certiorari.

The due process for petitions for such writs is not simply civil or criminal, because they incorporate the presumption of non authority, so that the official who is the respondent has the burden to prove his authority to do or not do something, failing which the court has no discretion but to decide for the petitioner, who may be any person, not just an interested party. In this they differ from a motion in a civil process in which the burden of proof is on the Petitioner and in which there can be a question of "locus standi".

\section{Indian law}

Under the Indian legal system, parts of the prerogative writs are embodied in the Constitution of India. The jurisdiction to issue 'prerogative writs' is given to the Supreme Court, i.e., the Apex Court of India, under Article 32 of the Constitution for enforcement of Fundamental Rights and under Articles 139 for enforcement of rights other than Fundamental Rights; and to the High Courts of Judicature of all Indian states, i.e., the superior courts of the States, under Articles 226 of the Constitution.

The Constitution of India broadly provides for five kinds of "prerogative" writs: habeas corpus, certiorari, mandamus, quo warranto and prohibition.

- The writ of prohibition is issued by a higher court to a lower court prohibiting it from taking up a case because it falls outside the jurisdiction of the lower court. Thus, the higher court transfers the case to itself.

- The writ of habeas corpus is issued to a detaining authority, ordering the detainer to produce the detained person in the issuing court, along with the cause of his or her detention. If the detention is found to be illegal, the court issues an order to set the person free.

(Writ of habeas corpus is not only to ask a detainer to produce the detainee in the court. It can be used also if a person is missing and the police are not taking any action, such as when a person is suspected to be detained by an influential person. The law says producing the body of the person, meaning he should be produced whether dead or alive. In fact writ of habeas corpus has scope for wide application).

- The writ of certiorari is issued to a lower court directing that the record of a case be sent up for review, together with all supporting files, evidence and documents, usually with the intention of overruling the judgement of the lower court. It is one of the mechanisms by which the fundamental rights of the citizens are upheld. 
- The writ of mandamus is issued to a subordinate court, an officer of government, or a corporation or other institution commanding the performance of certain acts or duties.

- The writ of quo warranto is issued against a person who claims or usurps a public office. Through this writ the court inquires 'by what authority' the person supports his or her claim.

\section{What is writ jurisdiction?}

To ensure "rule of law" is followed by all government officials and departments, judicial review is called for through writ jurisdiction of courts. In modern democratic countries, the administrative authorities are vested with vast discretionary powers. The exercise of those powers often becomes subjective in the absence of accountability. Hence the need for a control of the discretionary powers is essential to ensure that 'rule of law' exist in all governmental actions. The judicial review of administrative actions in the form of writ jurisdiction is to ensure that the decisions taken by the authorities are legal, rational, proper, fair and reasonable.

Articles 32 and 226 of the Constitution of India have been designed for the enforcement of fundamental rights and for a judicial review of administrative actions, in the form of writs. It is a constitutional remedy available to a person to bring his complaint or grievance against any administrative action to the notice of the court. Safeguard of fundamental rights and assurance of natural justice are the most important components of writ jurisdiction.

All authorities falling within the meaning of "State" under Article 12 of the Constitution of India are amenable to Writ Jurisdiction. The declaration of fundamental rights would be meaningless unless these rights can be enforced at the instance of the persons on whom they are conferred. The Constitution itself has laid down the following provisions for the enforcement of the fundamental rights:

a. Any act of the executive or of the Legislature which takes away or abridges the fundamental rights shall be void and the courts are empowered to declare such act as void (Article 13).

b. The Supreme Court and the High Courts are empowered to issue writs for the enforcement of fundamental rights against any authority of the State.

Article 12 has defined "State" to include the Government and Parliament of India, and the Government and Legislature of the States, and all local or other authorities within the territory of India or under the control of the Government of India. The expression "other authorities" has been interpreted to cover even business organisations like Life Insurance Corporation of India and therefore such organisations also are amenable to the writ jurisdiction of the courts. A proceeding under Article 32 is described as a constitutional remedy and the right to bring such proceedings before the Supreme Court is itself a fundamental right. 


\section{Articles 32 and 226 of the Constitution of India}

Article 32 para. (1) guarantee a person the right to move the Supreme Court for the enforcement of fundamental rights guaranteed by part III of the constitution. Article 32 para. (2) empowers the Supreme Court to issue direction or orders or writs in the nature of habeas corpus, certiorari, prohibition, mandamus and quo warranto for the enforcement of fundamental rights.

Article 226 empowers the state High Courts to issue directions, orders or writs as mentioned above for the enforcement of fundamental rights and for "any other purpose". l.e., High courts can exercise the power of writs not only for the enforcement of fundamental rights but also for issues that may go beyond infringement of fundamental rights and for which there is no alternate remedy available under existing law.

Further, matters of public interest and importance, filed in the form of public interest litigation through writ petitions are also heard by both - the Supreme Court and the State High Courts.

Matters in which interest of the public at large is involved can be moved before the Supreme Court of India by any individual or group of persons by filing a Writ Petition highlighting the question of public importance for invoking this jurisdiction. Such concept is popularly known as "Public Interest Litigation" and several matters of public importance have become landmark cases. This concept is unique to the Supreme Court of India only and perhaps no other Court in the world has been exercising this extraordinary jurisdiction.

\section{Principles of exercise of writ jurisdiction}

The writ jurisdiction exercised by the Supreme Court under Article 32 of the Constitution of India and by the State High Courts under Article 226 of the Constitution of India for the enforcement of fundamental rights is mandatory and not discretionary. But the Writ Jurisdiction of the State High Courts for "any other purpose" is discretionary whereby the High Courts have the great responsibility of exercising this jurisdiction strictly in accordance with judicial considerations and well established principles.

Sometimes the courts abstain from hearing a Writ Petition by invoke the doctrine of Forum non conveniens, a discretionary power that allows courts to dismiss a case where another court (or forum) is much better suited to hear the case. This dismissal does not prevent a plaintiff from re-filing his or her case in the more appropriate forum.

Writs are meant as prerogative remedies. The five writs incorporated under Articles 32 and 226 of the Constitution of India are known as prerogative writs in English law because they were originated in the king's prerogative power of superintendence over the due observance of law by his officers and tribunals. Such prerogative writs are extraordinary remedies. When ordinary legal remedies seem inadequate, in exceptional cases, writs are applied. 


\section{The prerogative writs - their application, procedure and grounds}

\section{for application in India}

\section{Habeas corpus}

The meaning of the Latin phrase "habeas corpus" is "have the body". According to Article 21 of the Constitution of India, "no person shall be deprived of his life or personal liberty except according to the procedure established by law". The writ of habeas corpus is in the nature of an order directing a person who has detained another, to produce the latter before the court in order to examine the legality of the detention and to set him free if there is no legal justification for the detention. It is a process by which an individual who has been deprived of his personal liberty can test the validity of the act before a higher court.

The objective of the writ of habeas corpus is to provide for a speedy judicial review of alleged unlawful restraint on liberty. It aims not at the punishment of the wrongdoer but to resume the release of the retinue. The writ of habeas corpus enables the immediate determination of the right of the appellant's freedom.

Article 22 of the Constitution of India requires an arrested person to be produced within 24 hours of his arrest and failure to do so would entitle the person arrested to be released. The grounds of his arrest should also be informed to him. Even when the arrest is valid, failure to inform the grounds within a reasonable time would make the detention unconstitutional. In such cases, the writ of habeas corpus acts as a constitutional privilege. If the court finds that there was no legal ground for the imprisonment of a person, it will pass an order to release him forthwith. The question before the court is whether the detention is lawful. In the writs of habeas corpus, the merits of the case or the moral justification for the imprisonment or detention are irrelevant. Any person whether he is guilty or not, is entitled to be set at liberty if his imprisonment is not as per law.

\section{Who can apply?}

A writ of habeas corpus is issued to the authority or person who has detained the person. The application for habeas corpus can be made by the prisoner himself or by any interested person other than a total stranger. Even a letter to the court pointing out the illegalities of imprisonment or unlawful detention may be admitted. If the court gets any information from anyone, it can act suo motu in the interest of justice.

\section{Procedure}

An application for a writ of habeas corpus has to be made along with an affidavit describing the nature and circumstances of the restraint. If the court finds that a prima facie case for granting the request is evident, then it will issue a rule "nisi" calling upon the authority concerned to show cause, on a specified date, why the writ should not be issued. If the cause shown is found to be insufficient, the court will issue the writ for the immediate release of the detained person. 


\section{Habeas corpus and the emergency powers of the executive}

Various legislations have curtailed the power of this writ to a great extent. For example, the declaration of emergency and other national security laws of India whereby the executive has the power to detain a person at its discretion preventively. As per the existing national security laws, the grounds of arrest need not be revealed to the person arrested. In such instances, the judiciary has very little scope for interference.

Similarly, Article 359 of the Constitution of India empowers the president of India to suspend the right to move any court for the enforcement of any of the fundamental right, specified in his order.

\section{Certiorari}

The writ of certiorari is generally issued against authorities exercising quasi-judicial functions. The Latin word certiorari means "to certify". Certiorari can be defined as a judicial order of the Supreme Court or of a State High Court to an inferior court or to any other authority that exercise judicial, quasi-judicial or administrative functions, to transmit to the court the records of proceedings pending with them for scrutiny and to decide the legality and validity of the order passed by them.

Through this writ, the court quashes or declares invalid a decision taken by the concerned authority. Though it was meant as a supervisory jurisdiction over inferior courts originally, these remedy is extended to all authorities who issue similar functions. The concept of natural justice and the requirement of fairness in actions, the scope of certiorari have been extended even to administrative decisions. Whether the decision is judicial or quasi-judicial is irrelevant nowadays.

Certiorari is corrective in nature. This writ can be issued to any constitutional, statutory or non statutory body or any person who exercise powers affecting the rights of citizens.

\section{Grounds for certiorari}

The following are the grounds for certiorari:

\section{a. Lack of jurisdiction}

When the authority has no jurisdiction to take action, it is lack of jurisdiction. When an authority is improperly constituted or is incompetent to take action and if it acts under an invalid law, it will amount to lack of jurisdiction. Similarly when the authority acts without jurisdiction, fails to exercise the vested jurisdiction or acts in excess of the limits, there involves a defect of jurisdiction or power. The court can issue certiorari to quash such orders.

\section{b. Abuse of jurisdiction}

If an authority abuses its jurisdiction, a certiorari can be issued. When the authority exercises its power for improper purposes it is abuse of jurisdiction. Similarly if the 
authority acts in bad faith or ignores relevant points and facts or acts on some other considerations abuse of jurisdiction occurs and the writ of certiorari becomes applicable.

c. Jurisdictional facts

A jurisdictional fact is that fact or facts upon which an authority's power to act depends. In the absence of jurisdiction for collateral facts an authority cannot exercise jurisdiction over a dispute and decide it. If the authority takes a decision on the wrong assumption of existence of jurisdictional facts, the order is liable to be quashed by the writ of certiorari.

d. Error of law apparent on the face of record

A writ of certiorari can be issued to quash an order if there is an error of law apparent on the record. An error is apparent on the face of record if it is self-evident. l.e., if the error can be ascertained by a mere perusal of the record without a detailed argument or further evidence. An error of law apparent on the face of the record is treated as an insult to the legal system. Ignorance or neglect of law, wrong proposition of law, inconsistency between the facts, law and the decision etc. amount to errors of law.

e. Violation of the principle of natural justice

When there is a violation of the principle of natural justice, a writ of certiorari can be issued. An authority is bound to observe the principles of natural justice. Anyone who decides a case must adhere to the minimum standards of natural justice. Hence when there occurs an infraction of fundamental right, the writ of certiorari comes for restoration of that right.

\section{Prohibition}

The grounds for issuing the writs of certiorari and prohibition are generally the same. They have many common features too. The writ of prohibition is a judicial order issued to a constitutional, statutory or non-statutory body or person if it exceeds its jurisdiction or it tries to exercise a jurisdiction not vested upon them. It is a general remedy for the control of judicial, quasi-judicial and administrative decisions affecting the rights of persons.

\section{Grounds}

The writs of prohibition and certiorari are issued more or less on similar grounds.

a. Absence or excess of jurisdiction

The writ if prohibition prohibits an authority from exercising a jurisdiction not vested on it. When there is absence of jurisdiction or total lack of jurisdiction an authority cannot act.

\section{b. Violation of fundamental rights}

When an authority acts in violation or infringement of the fundamental rights of a person, a writ of prohibition can be invoked. 
c. Violation of the principles of natural justice

All authorities are to observe the principles of natural justice while exercising their powers. If an authority fails in this regard the decision of that authority is liable to be quashed through the writ of prohibition.

d. Statutes or laws against the Constitution

When an authority tries to act under a statute or a law which is unconstitutional, the writ of prohibition can be applied.

Common features of prohibition and certiorari:

- Issued against any authority having judicial, quasi-judicial or administrative jurisdiction.

- Certiorari is issued to quash a decision already taken whereas prohibition is issued when the matter is still pending before the authority. But even if the authority has taken a decision, the writ of prohibition can be issued to stop the authority from enforcing the decision.

- Certiorari can be applied for both prevention and cure whereas prohibition is mainly for prevention.

\section{Mandamus}

The writ of mandamus is a judicial remedy in the form of an order from the supreme court or high courts to any inferior court, government or any other public authority to carry out a "public duty" entrusted upon them either by statute or by common law or to refrain from doing a specific act which that authority is bound to refrain from doing under the law. For the grant of the writ of mandamus there must be a public duty. The superior courts command an authority to perform a public duty or to non-perform an act which is against the law. The word meaning in Latin is "we command".

The writ of mandamus is issued to any authority which enjoys judicial, quasi-judicial or administrative power. The main objective of this writ is to keep the public authorities within the purview of their jurisdiction while performing public duties.

\section{Conditions required for mandamus}

- The petitioner must have the right to compel the performance of the duty. This writ cannot be invoked if the person complaining has no legal right.

- There must be public duty. That duty must be mandatory and not discretionary. But at the same time when a discretionary power is abused or improperly exercised, that would be treated as non exercise of discretion and the court can command the authority to exercise the discretion in accordance with law.

- The petitioner must have made a specific demand for the performance of the duty and the authority must have made a refusal to perform. Then only a writ of mandamus can be sought.

- A civil liability arising under a contract cannot be enforced through mandamus. The grant of mandamus is discretionary. If there is unreasonable delay in filing the petition or if there is an adequate alternate remedy mandamus may be refused by the court. 
Harsh PATHAK

\section{Grounds}

The grounds for the writ of mandamus are similar to those of certiorari and prohibition:

a. lack of jurisdiction;

b. error of jurisdiction;

c. excess jurisdiction;

d. abuse of jurisdiction;

e. violation of the principles of natural justice;

f. error of law apparent on the face of the record etc.

In the modern age, administrative agencies enjoy vast discretionary powers. Judicial review of the administrative actions often becomes necessary. The judicial review of administrative functions also comes under the scope of mandamus. When an administrative authority who has the power of discretion fails to act bona fide or if it abuses or exceeds the jurisdiction and if it does not apply "mind" in solving issues the writ of mandamus acts as an extraordinary remedy.

\section{Who can apply?}

Generally the affected person has the right to seek this remedy. Exceptions are:

a. The writ of mandamus cannot be issued against the president or the governors of states. They cannot be insisted to exercise powers and to perform duties.

b. The writ of mandamus cannot be issued against the state legislature to prevent it from the execution of a law alleged to be violative of the provisions of the Constitution.

c. The writ of mandamus cannot be issued to an officer who acts on the orders of his superior.

\section{Grounds for refusal of mandamus}

Mandamus is a public law remedy and hence it cannot be used to enforce a civil liberty arising under contracts. If there is unreasonable delay in filing the petition and if there is another adequate alternate remedy, the writ of mandamus cannot be issued.

In fact, the writ of mandamus is more purposeful than certiorari or prohibition. It combines the aspects of both the writs to make an effective and better solution.

\section{Quo warranto}

The word meaning of "quo warranto" is "by what authority". It is a judicial order against a person who occupies a substantive public office without any legal authority. The person is asked to show by what authority he occupies the position or office. This writ is meant to oust persons, who are not legally qualified, for substantive public posts.

The writ of quo warranto is to confirm the right of citizens to hold public offices. In this writ the court or the judiciary reviews the action of the executive with regard to appointments made against statutory provisions, to public offices. It also aims to protect those persons who are deprived of their right to hold a public office. 


\section{Conditions}

The following conditions are to be present if the writ of quo warranto is to be issued:

- The office must be a 'public office'. All offices established by statutes or as per the provisions of the constitution and which carry out public duties are public offices.

- It must be substantive in nature. A substantive office is independent and permanent. It must be held by an independent officer.

- The holder must be in actual possession of the office.

- The person must have actual possession of the office. A person who has been elected or appointed to a particular post cannot be sued upon unless he has not accepted the post.

- The holding of the post must be in contravention of law.

The appointment of a person to a public office must be a clear violation of law. Irregularities in procedures etc. cannot be taken as violation.

\section{Who can apply?}

Any member of the public can seek the remedy of quo warranto even if he is not personally aggrieved or interested in the matter.

\section{Landmark case-law}

\section{Kesavananda Bharati vs. State of Kerala, (1973) 4 SCC 225}

In this case, the validity of $24^{\text {th }}, 25^{\text {th }}$ and $29^{\text {th }}$ amendments to the Constitution of India was challenged. The main question related to the nature, extent and scope of amending power of the Parliament under the Constitution. The basic structure doctrine was laid down in this case. The basic structure doctrine is an Indian judicial principle that the Constitution of India has certain basic features that cannot be altered or destroyed through amendments by the parliament. Key among these "basic features", are the fundamental rights and individual freedom granted by the constitution. The Hon'ble Supreme Court held that Article 368 of the Constitution does not enable Parliament to alter the basic structure of frame-work of the constitution. It was further held that the amendment of Article 368 para. (4) excluding judicial review of a constitutional amendment was unconstitutional and the amendment of Article $31 \mathrm{C}$ containing the words "and no law containing a declaration that it is for giving effect to such policy shall be called in question in any court on the ground that it does not give effect to such policy" was also held invalid.

\section{Radhey Shyam \& Anr. vs. Chhabi Nath \& Ors., (2015) 5 SCC 423}

The Jurisdiction under Articles 32 and 226 of the Constitution of India has been explained by the Hon'ble Supreme Court in this case as under:

" 6 . The language used in Articles 32 and 226 of our Constitution is very wide and the powers of the Supreme Court as well as of all the High Courts in India extend to 
issuing of orders, writs or directions including writs in the nature of habeas corpus, mandamus, quo warranto, prohibition and certiorari as may be considered necessary for enforcement of the fundamental rights and in the case of the High Courts, for other purposes as well. In view of the express provisions in our Constitution we need not now look back to the early history or the procedural technicalities of these writs in English law, nor feel oppressed by any difference or change of opinion expressed in particular cases by English Judges. We can make an order or issue a writ in the nature of certiorari in all appropriate cases and in appropriate manner, so long as we keep to the broad and fundamental principles that regulate the exercise of jurisdiction in the matter of granting such writs in English law".

\section{Shreya Singhal vs. Union of India, (2015) 5 SCC 1}

In this case, the Hon'ble Supreme Court observed that the writ petition under Article 32 of the Constitution of India raised very important and far-reaching questions relatable primarily to the fundamental right of free speech and expression guaranteed by Article 19 para. (1) letter a) of the Constitution of India. The immediate cause for concern in the petition was Section 66A of the Information Technology Act of 2000. This Section was not in the Act as originally enacted, but came into force by virtue of an Amendment Act of 2009 with effect from 27 October 2009. The Hon'ble Supreme Court, exercising its Writ Jurisdiction, held that Section 66A arbitrarily, excessively and disproportionately invades the right of free speech and upsets the balance between such right and the reasonable restrictions that may be imposed on such right.

\section{Riju Prasad Sarma Etc.Etc vs. State Of Assam \& Ors, (2015) 9 SCC 461}

The Supreme Court of India, in this case, made it clear that judiciary in India, acting on its judicial side cannot be considered as a State under Article 12 of the Constitution, and that only when the courts deal with their employees or act in other matters purely in administrative capacity, they may fall within the definition of the State for attracting writ jurisdiction. The Supreme Court also ruled that writs against the judiciary would lie against their administrative actions alone.

\section{Conclusion}

In India, the rule of law is supreme and judiciary has the right to interfere whenever there is deviation from this supremacy. Writ jurisdiction is judicial reviews of administrative actions. The Judiciary stands to ensure that all administrative actions are confined to the limits of the law and examines administrative action to assess whether the authority has exercised its powers, whether the authority has abused or exceeded its powers, whether the authority has committed an error of law, whether the authority has violated the principles of natural justice, whether the authority has infringed the fundamental rights of persons. Thus, the writ jurisdiction is a judicial restraint on policy decisions which are unreasonable, unfair and against public interest. 